\title{
Latest data on distribution of the Pygmy Owl (Glaucidium passerinum) in Bulgaria and Slovakia including population density comparison
}

\author{
Aktuálne poznatky o rozšírení kuvička vrabčieho (Glaucidium passerinum) v Bulharsku \\ a na Slovensku s porovnaním denzít populácií
}

\author{
Samuel PAČENOVSKÝ \& Peter SHURULINKOV
}

\begin{abstract}
Pačenovský S \& Shurulinkov P 2008: Latest data on distribution of the Pygmy Owl (Glaucidium passerinum) in Bulgaria and Slovakia including population density comparison. Slovak Rapt J 2: 91-106.
\end{abstract}

\begin{abstract}
The authors provide an outline of actual knowledge on the distribution of the Pygmy Owl (Glaucidium passerinum) in Bulgaria from 1900 until 2008. The most recent estimates of the species population in Bulgaria are 150-200 and in Slovakia 1500-2000 breeding pairs. On the basis of quantitative samples obtained in the Rila Mts (Bulgaria) and in the High and Western Tatra Mts, Low Tatra Mts, "Krivánska Malá Fatra” Mts, "Vel’ká Fatra” Mts, "Chočské vrchy” Mts, "Stolické vrchy” Mts (Slovakia) obtained densities in Bulgaria are compared with ascertained densities in similar elevations in Slovakia. In the Rila Mts, 9 territories were found $/ 23 \mathrm{~km}^{2}$ and average density 0.39 territories / $1 \mathrm{~km}^{2}$ was found, in 1350-2000 m elevation. In Slovakia 75-82 territories were found $/ 79 \mathrm{~km}^{2}$ and average density $0.95-1.04$ territories / $1 \mathrm{~km}^{2}$ was found, in $800-1650 \mathrm{~m}$ elevation. The density of Pygmy Owls in the mountains of Bulgaria is twice as low as in the mountains of Slovakia in Western Carpathians. This is probably caused by the distribution at the edge of the distribution area of the species and an higher isolation level in the Balkans. Other evaluated factors, such as habitat quality, health of forest stands, shorter twilight and shorter owl activity in the Balkans than in the Carpathians, negative effect of streams on voice activity of the Pygmy Owls, lack of food supply or lack of breeding holes, or even possible competition with other owl species were not regarded as reasons causing differences in Pygmy Owl densities in compared areas.
\end{abstract}

\begin{abstract}
Abstrakt: Autori podávajú prehl'ad aktuálnych poznakov o výskyte a rozšírení kuvička vrabčieho (Glaucidium passerinum) v Bulharsku od roku 1900 do roku 2008. Posledné odhady populácie druhu v Bulharsku sú 150-200 párov a na Slovensku 1500-2000 párov. Na základe kvantitatívnych vzoriek získaných v pohorí Rila (Bulharsko) a v pohoriach Slovenska - Západné a Vysoké Tatry, Nízke Tatry, Krivánska Malá Fatra, Vel'ká Fatra, Chočské vrchy, Stolické vrchy sa porovnali získané denzity v pohoriach Bulharska s denzitami zistenými v podobných nadmorských výškach na Slovensku. V pohorí Rila (Bulharsko) bolo zistených 9 teritórií kuvičkov na $23 \mathrm{~km}^{2}$ skúmanej plochy a priemerná denzita vychádza 0,39 teritórií / 1 km². V západokarpatských vysokých pohoriach Slovenska bolo zistených 75-82 teritórií / 79 km² skúmanej plochy a priemerná denzita vychádza 0,95-1,04 teritórií na $1 \mathrm{~km}^{2}$. Viac ako dvojnásobne nižšie denzity kuvičkov vrabčích v pohoriach Bulharska ako v pohoriach Západných Karpát na Slovensku sa prisudzujú okrajovému rozšíreniu a značnej izolácii druhu na Balkáne, kým iné možné faktory, ako napr. kvalita biotopu, zdravotný stav porastov, kratší súmrak na Balkáne a tomu zodpovedajúca kratšia hlasová aktivita kuvička vrabčieho ako v Karpatoch, negatívny vplyv prirodzeného hluku - najmä horských potokov na hlasovú aktivitu kuvičkov, nedostatok potravy či stromových dutín, alebo možná kompetícia s inými druhmi sov sa autormi nepovažovali za dôvody, ktoré by mohli dostatočne zdôvodnit' rozdielne denzity kuvička vrabčieho na dvoch porovnávaných územiach.
\end{abstract}

Key words: Pygmy Owl, population estimates, density, Bulgaria, Slovakia

Samuel Pačenovský, SOS/BirdLife Slovakia, Tatranská 2, SK-040 01 Košice, Slovakia. E-mail: pacenovsky@vtaky.sk. Peter Shurulinkov, Institute of Zoology, Bulgarian Academy of Sciences, BG-1000 Sofia, boul. Tsar Osvoboditel 1, Bulgaria. E-mail: shurulinkov@mail.bg.

Acknowledgement: We are sincerely grateful to Mr. D. Nankinov for providing consultations in our work, for Andrej Ralev, Boris Nikolov, Petko Tzvetkov, Emil Komitov, Georgi Stoyanov, Girgina Daskalova and Krassimir Hristov, for fieldwork in Bulgaria, for Erik Baláž, Peter Vrlík, Róbert Olejár and many others for help in fieldwork in Slovakia, for Gerard Gorman for useful comments in preparation of the work and providing additional data and for Mike Black for correcting the text. 


\section{Introduction}

The Pygmy Owl is regarded as a rare species with isolated distribution in Bulgaria (Tabs 1 and 2). Simeonov et al. (1990) considered it to be an extinct species, latest European and world sources "mention existence of isolated populations in the Bulgarian Balkan and Rhodopes mountains" (Mikkola \& Sackl 1999), or "small isolated populations in Rodopi Mts of Bulgaria" (del Hoyo et al. 1999) respectively.

Second author prepared an outline of all 22 recently (and previously) accepted records of Pygmy Owl from 1900 till the end of October 2005 from Bulgaria from 5 different mountain ranges: the Rila Mountains, the Pirin Mts, the Slavyanka Mts, the Central Balkan (Stara planina) Mts and the Rhodopes Mts (Tab. 1).

First author carried out an evaluation of two local quantitative samples of Pygmy Owl's densities from the Rila Mountains in Bulgaria from autumn 2003 and 2005 and compared the densities with quantitative samples obtained by comparable methods from 6 mountain areas in Slovakia over $1000 \mathrm{~m}$ elevation from years 1990-2002.

Known densities from different European countries (Bulgaria, Slovakia, Germany, the Czech Republic, Finland) are discussed further.

\section{Methods}

Evaluation of data from Bulgaria was based on gathering and selecting information published in literature by the second author and by interpretation of data gathered by both authors.

Listening of spontaneous territorial calls of Pygmy Owls in suitable mountain habitats in the Rila Mountains, in coniferous and mixed forests (spruce, beech-fir, beech-fir-spruce in Slovakia and spruce, beech-fir, beech-fir-spruce with Bosnian Pine, Macedonian Pine and Scots Pine forests in Bulgaria) in elevations 1000-1650 m (Slovakia) and 1350-2000 m (Bulgaria) were carried out. The counts were made at the highest parts of the slopes of the valleys, far from streams, to gain optimal acoustic effect during the evening hours, at dusk (the counts started after sunset and lasted approximately one hour after sunset) and early in the morning, at dawn (approximately from one hour before sunrise till the sunrise).

In Bulgaria quantitative studies were conducted in autumn from early September untill the middle of October, during the autumn-mating season of owls with clear, rather frequent vocalisations.

To maximise effectiveness of the method, imitations of Pygmy Owl advertising calls were used, waiting for response of territorial owls. Both close and distant calls (approximately at one kilometer distance from the opposite slope of the valley) were evaluated. The goal was to map of owl territories.

In in 7 selected 7 high mountain areas of Slovakia (1000 $\mathrm{m}$ above sea level), the High Tatra Mts, the Western Tatra Mts, the Low Tatra Mts, the "Chočské vrchy" Mts, the "Vel'ká Fatra" Mts, the "Krivánska Malá Fatra" Mts, the "Stolické vrchy" Mts the quantitative studies were carried out both in early spring (February till mid of April) and in late summer / autumn seasons (August-November) using the same method as in Bulgaria, namely mapping of occupied territories in spruce, spruce-fir-beech and beech-fir forests, listening and evaluating various territorial calls [advertising calls, vibrating calls described by Mikkola (1983) and autumn calls described by Scherzinger (1970) and by Schönn (1972)] of Pygmy Owl. The survey of Pygmy Owls was done in high slopes over the valleys and on the ridges; the method was based on locating both close and distant, but clearly recognised calls. In autumn Pygmy Owls tend to call frequently, and they defend their territories just as well as they do in spring. So the territorial calls recorded both in spring, and during August - November consisting of advertising calls, vibrating territorial calls and "autumn songs" were treated as evidence of occupied territories. The method was based on information published by Scherzinger 1970: "pygmy owls give territorial calls during all year, and the autumn song has a strong territorial meaning" and proved by the first author's personal experience from many locations in Slovakia (Pačenovský 1990, 1992, 1994, 1995; Pačenovský \& Kürthy 1991, 1992; Pačenovský \& Matis 1997). Tape recordings of the Pygmy Owl's calls were not used during the studies. The practise of using imitation Pygmy Owl's calls to stimulate their responds is a method used widely in the Czech Republic with good results (Kloubec 1987, Janda \& Řepa 1986). We used these imitations to stimulate territorial calls of the owls. The advantage of gathering quantitative data on Pygmy Owls during autumn was relatively better access to the studied sites due to milder weather and less snowy conditions, than in early spring, both in Bulgarian and Slovakian mountains. By using this method, territories of Pygmy Owls recorded are those of adult males. This result could be interpreted as a territory of a potential breeding pair (hereinafter also bp.).

Additionally, calls of other species of owls were determined and evaluated during the quantitative surveys, but data of other species except that of the Pygmy Owl are treated as additional (not essential for the present study). Territories of Pygmy Owls recorded are those of adult males. This result could be understood as a territory of 


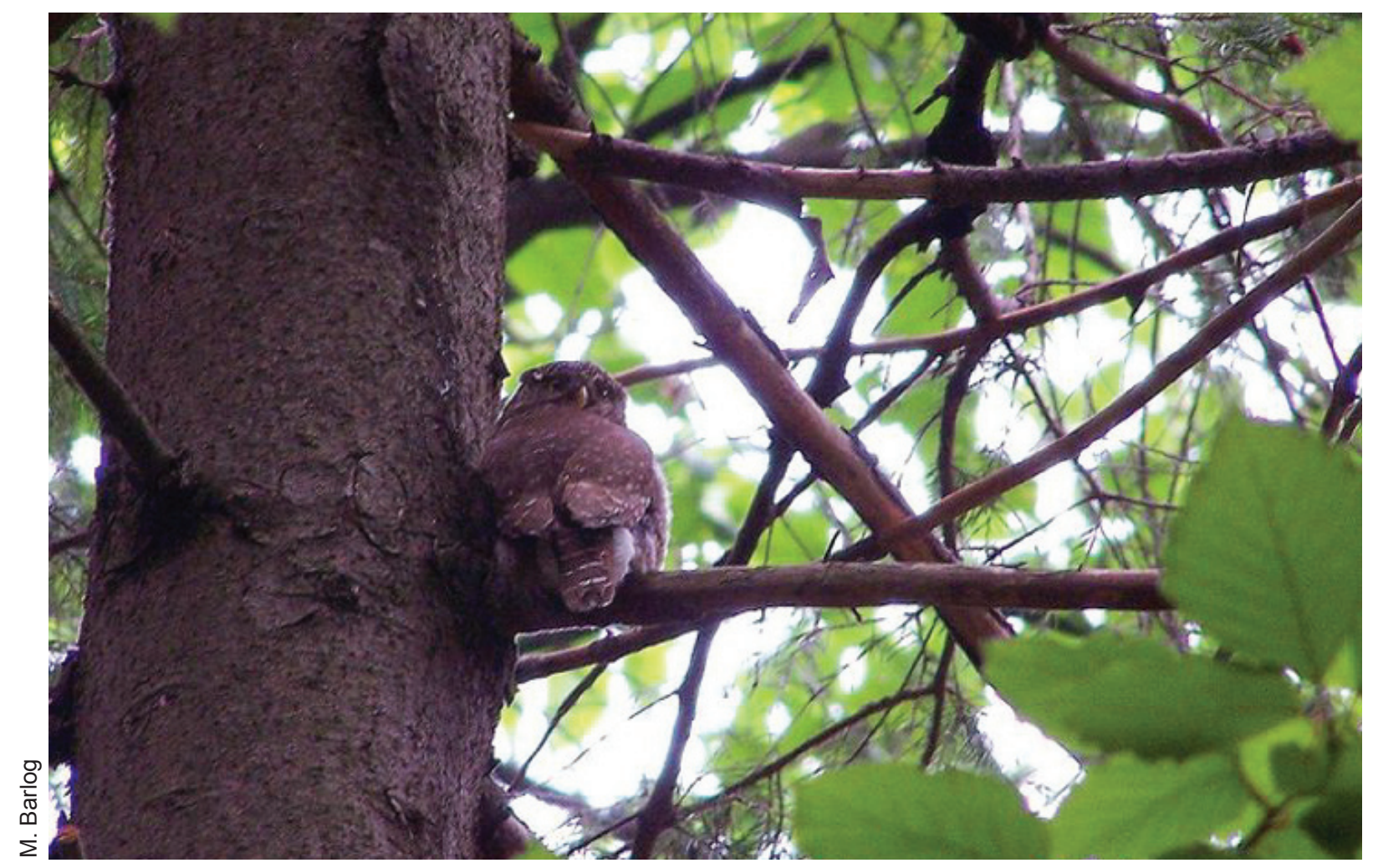

Fig. 1. Pygmy Owl in Slovenský raj National Park.

Obr. 1. Kuvičok vrabčí v Národnom parku Slovenský raj.

a potential breeding pair. Obtained quantitative data were not calculated for all mountain range area, regardless of different habitat types. All results of quantitative surveys in this study reflect only densities of Pygmy Owls suitable for forest habitats, where the surveys were carried out.

Owl counts, used for comparative data from Slovakia were done mainly in 2002, by S. Pačenovský, E. Baláž, R. Olejár and other contributors in areas proposed for SPAs. Data from the "Stolické vrchy" Mts were obtained by the first author during a systematic mapping survey, which provided data for the book "Birds Distribution in Slovakia" during 1995-1999 and also 1990-1994.

\section{Results}

Outline of the present status

Bulgaria. Total 24 accepted localities, 34-36 pairs found. Estimated breeding population for the whole country: 150-200 pairs, including: the Rila Mts $-60-80$ bp., the Pirin Mts $-15-20$ bp., the Slavjanka Mts - 5-6 bp., the Stara planina Mts $-20-30$ bp., the Rhodopes Mts $>50-60$ bp, but even much higher numbers could be expected there. Breeding occurred between 1020 and $1950 \mathrm{~m}$ a. s. 1., most often between 1400 and $1800 \mathrm{~m}$. The most preferred habitats include the following forest types: Spruce, spruce-beech, beech, beech-fir and beech-fir-spruce forests. Occasionally inhabits also Bosnian Pine, spruce-Macedonian-pine and spruce-scots-pine forests. In all cases found in old forest stands, usually older than 80-100 years.

Slovakia. Until the 1970 's the species was regarded to be distributed in most mountain ranges of Slovakia (Ferianc 1979), but very few quantitative data were known, or published. During the mapping of bird distribution for the atlas, covering the whole territory of the former Czechoslovakia in 1973-1977 the Slovak Republic was relatively poorly covered and Pygmy Owl was located as a breeding species in only $8 \%$ of $10 \times 10 \mathrm{~km}$ quadrates (proven breeding in 8 quadrates, assumed breeding in 10 quadrates and possible breeding in 22 quadrates).

In monography of Hudec (1983) on the distribution of birds in former Czechoslovakia (including Slovakia) the Pygmy Owl was characterised as a sedentary, rarely breeding species, wandering in winter months around breeding sites. 


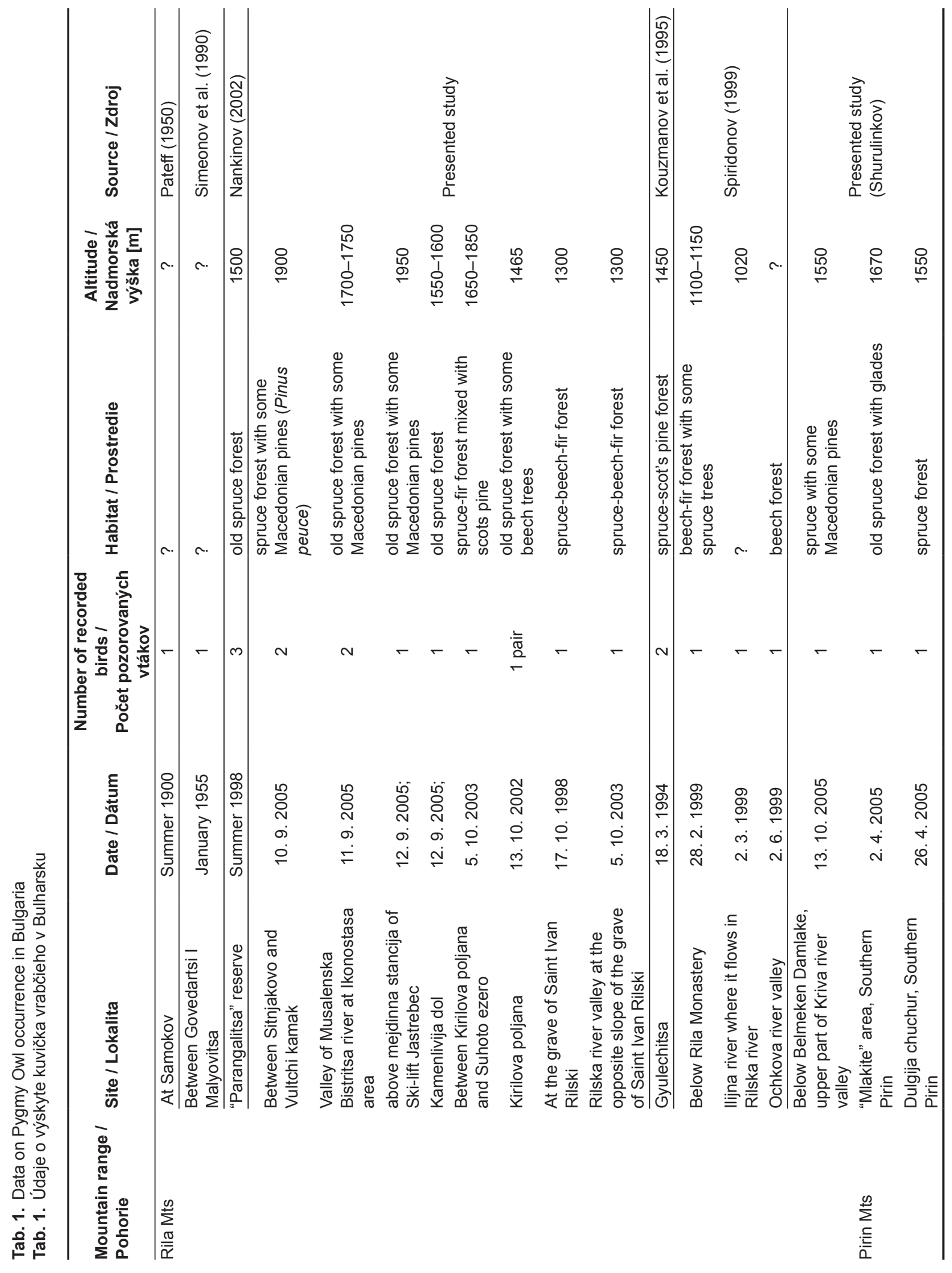




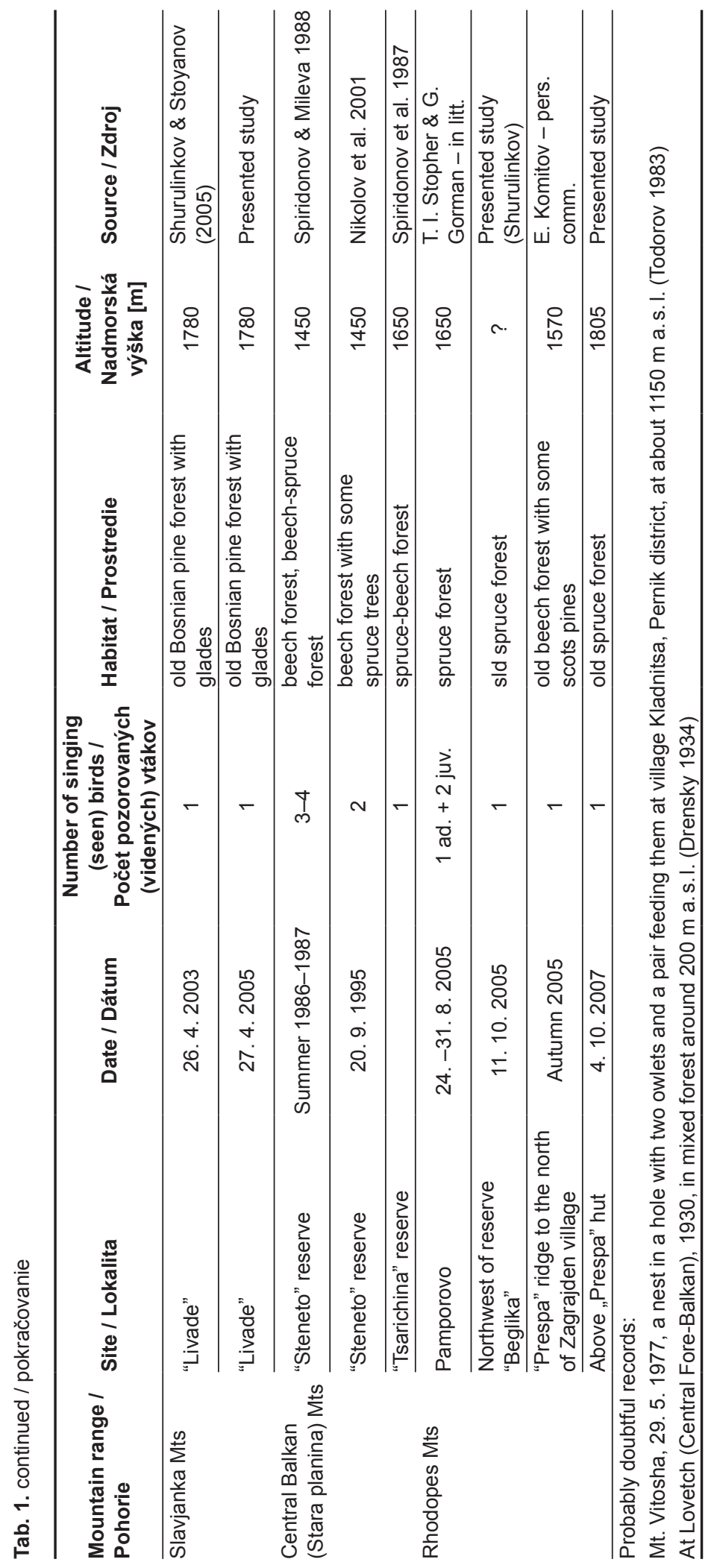


Tab. 2. Population estimates of the Pygmy Owl for the territory of Bulgaria based on published data (until 2008)

Tab. 2. Odhady početnosti kuvička vrabčieho na území Bulharska na základe publikovaných údajov (po 2008)

\begin{tabular}{cc}
\hline $\begin{array}{c}\text { Estimated number [pairs] } \\
\text { Odhadovaný počet [páry] }\end{array}$ & Source / Zdroj \\
\hline Extinct & Simeonov et al. 1990 \\
$5-10$ & Kostadinova 1997 \\
7 & Kostadinova \& Michailov 2002 \\
$\geq 20$ & Nankinov 2002 \\
$80-120$ & Nankinov et al. 2004 \\
$20-100$ & Birdlife International 2004 \\
$150-200$ & Presented study / Táto štúdia \\
\hline
\end{tabular}

Tab. 3. Population estimates for the Pygmy Owl in Slovakia Tab. 3. Odhady početnosti kuvička vrabčieho na Slovensku

\begin{tabular}{cc}
\hline $\begin{array}{c}\text { Estimated number [pairs] I } \\
\text { Odhadovaný počet [páry] }\end{array}$ & Source / Zdroj \\
\hline $\begin{array}{c}\text { Breeding assumed in } 8 \% \\
\text { of mapping quadrates in } \\
\text { Slovakia }\end{array}$ & $\begin{array}{c}\text { Štastný et al. (1987) } \\
\text { (data for Slovakia) }\end{array}$ \\
$\begin{array}{c}\text { 500-600 pairs } \\
\text { 1000-1500 pairs, breeding } \\
\text { assumed in 36.8 \% of } \\
\text { mapping quadrates }\end{array}$ & Murin et al. (1994) \\
1500 pairs & Danko et al. (2002) \\
$1500-2000$ pairs & ŠOP SR (2002) \\
\hline
\end{tabular}

All available data on the Pygmy Owl until 1897 from East Slovakia were summarised by Danko (1988). Most knowledge on the species was based on accidental observations, mentioned as part of lists of bird species observed at certain areas. Until 1987 about 42 records, including data on breeding, from most (17) mountain ranges of East Slovakia were available, which means, that the species was quite widespread and not that rare. However, the almost complete lack of knowledge on breeding was a result of little interest of ornithologists in this species. The opinion that its density would be higher, as was previously thought has since been proved. The first concrete data on breeding of the Pygmy Owl from East Slovakia were published by Klaus et al. (1982), Vlach in Rác (1987) and a further occasion of breeding was described in a paper of Danko (1988).

Further nests were found in East Slovakian Mountains in 1989 and soon were published along with information on breeding ecology and the first results of territorial mapping surveys and quantitative data from East Slovakia (Pačenovský 1990, 1992, 1993; Pačenovský \& Kürthy 1991, 1992).
Knowledge on the distribution of the species has seriously improved after atlas-mapping covering the whole of Slovakia in 1995-1999, because the Pygmy Owl is on the list of SPEC species designed to establish SPAs. After the results of field studies with the aim of estimating proper densities of the owl at the most valuable areas for distribution of mountain species in higher (over $1000 \mathrm{~m}$ elevation) mountainous areas of Slovakia with large portions of well preserved coniferous and mixed (e.g. fir-beech) forests these data were used also in the designation of certain SPA areas in 2002. The distribution of the species is now well known in Slovakia, it covers $36 \%$ of the mapping quadtrates (Danko et al. 1999). The species is distributed evenly in the mountains of Central and Eastern Slovakia. Development of estimates of the country population is summarised in table 3 .

\section{Densities of the Pygmy Owl \\ Bulgaria}

1. Central part of the Rila Mountains, in the Rilska River (Rilska reka) valley; October 4-5, 2003 (S. Pačenovský, A. Ralev, P. Shurulinkov); 1100-1800 m a.s. 1., 100-150 years old coniferous (spruce-fir-pine) and mixed (spruce-beech) forests.

At total survey area $13 \mathrm{~km}^{2}$ in $900-1800 \mathrm{~m}$ elevation vocalisations of 2 males of the Pygmy Owl (Glaucidium passerinum) was recorded. Approximation of occupied territories (female birds were affiliated to the closest male's territory) on area of $1 \mathrm{~km}^{2}$ provides the following densities: 0.15 territories $/ 1 \mathrm{~km}^{2}$. The first Pygmy Owl was heard by S. Pačenovský and A. Ralev between 6.15 and 6.58 (of $\mathrm{G}+1$ time) on Ocober, 5. Advertising calls of a male Pygmy Owl and autumn calls were heard, probably from the same bird. The calls came from the steep Southern slope from an old (approx. 120 years) spruce-fir grow in 1600-1800 m elevation, close to upper tree line, East from settlement Kirilova poljana.

The second Pygmy Owl was heard from the Northern slope of the valley, a distant call of a male and an autumn call was heard 4 times by all observers, it was heard from the opposite slope of the valley, from about $800 \mathrm{~m}$ distance, during dusk at the same day, October, 5. The habitat consisted of a mixed forest of spruce and beech, 100-150 years old, situated in lower third of the valley slope, in 1100-1200 elevation, about $6 \mathrm{~km}$ east from the "Rilski Monastyr".

There are also some other data from the same area. On October 17, 1998, Spiridonov found one specimen of the Pygmy Owl at the grave of "Saint Ivan Rilski" 
Slovak Rapt J 2008, 2: 91-106. DOI: 10.2478/v10262-012-0023-5.

(C) Raptor Protection of Slovakia (RPS)

Tab. 4. Ascertained densities of Glaucidium passerinum in the Rila Mts in Bulgaria

Tab. 4. Zistené denzity Glaucidium passerinum v pohorí Rila v Bulharsku

\begin{tabular}{|c|c|c|c|}
\hline $\begin{array}{l}\text { Site, region (period) // } \\
\text { Lokalita, oblast' (obdobie) }\end{array}$ & $\begin{array}{c}\text { Number of territories (pairs) / } \\
\text { area }\left[\mathrm{km}^{2}\right] / / \\
\text { Počet teritórií (páry) / územie } \\
{\left[\mathrm{km}^{2}\right]}\end{array}$ & $\begin{array}{l}\text { Density in territories } / 1 \mathrm{~km}^{2} / / \\
\text { Denzita } \mathrm{v} \text { teritóriách } / 1 \mathrm{~km}^{2}\end{array}$ & $\begin{array}{c}\text { Average size of territory // } \\
\text { Priemerná vel'kost' teritória } \\
{\left[\mathrm{km}^{2}\right]}\end{array}$ \\
\hline Rilska Reka (1998-2003) & $3 / 13$ & 0.23 & 4.33 \\
\hline Borovets (2005) & $6 / 10$ & 0.60 & 1.67 \\
\hline Rila Mts (average density) & $9 / 23$ & 0.60 & 2.60 \\
\hline
\end{tabular}

(Spiridonov 1999). During our survey we did not hear any Pygmy Owl in this locality, but due to the wind and noise coming from bottom of the valley (bubbling of the stream), it is possible, that we could have missed the calls of the bird. Also other explanations are: this territory could be empty in 2003 , or the territorial male could stay silent. Time span of the study is too short to evaluate, which assumption is right. The male Pygmy Owl calling on October, 5 from the opposite slope of the valley could belong to another occupied territory, according to knowledge on the size of Pygmy Owl territories (size of a territory in Central Europe is usually between $30-100$ ha and in case of large valleys it does not tend to spread from one slope of a large valley to the opposite slope).

On October 13, 2002 both authors located calls of a Pygmy Owl close to Kirilova polyana. According to knowledge on the size of Pygmy Owl territories this bird could belong to the same territory defended by a male bird on October 5, 2003 higher up on the same slope, about $500 \mathrm{~m}$ apart.

Final summary of densities of Pygmy Owls in an area of $13 \mathrm{~km}^{2}$ in the Rila valley, monitored during 1998-2003 (in greater detail on October 4-5, 2003) is 3 occupied territories of Pygmy Owls (1 at Kirilova poljana, 2 at grave of Saint Ivan Rilski), thus a density of 1 territory per $0.23 \mathrm{~km}^{2}$.

2. Northern part of the Rila Mts, at Borovets, in Valley of Musalenska Bistritsa River, at Sitnyakovo and in Kamenliva valley; September 10-12, 2005. First author obtained quantitative data of 6 Pygmy Owls from this area.

Record 1. On September 10, 2005 early morning from 6.13 till $6.18(\mathrm{G}+1)$ a male Pygmy Owl has called between Sitnjakovo and Vultchi kamak, on about 10 occasions giving a long series of territorial advertising calls. Then after a break it gave aproximately 5 series of "tremolo" advertising calls. Finally it gave one long (strongly territorial) autumn call. The owl has called from the spruce tree situated directly in front of the observer, at the tourist track.
Elevation of the site is $1900 \mathrm{~m}$; the habitat is an old spruce forest with some Macedonian pines (Pinus peuce).

Record 2. Another Pygmy Owl has called at the same time of the morning just $200 \mathrm{~m}$ apart, in NNW direction, below the track. At $6.14 \mathrm{~h}$ it made an autumn call. This is also a call of an adult territorial bird, but it could be another male, or a female as it is not possible to distinguish the sex of a bird from this call. However, we are sure it was another specimen, different from the first male, because of their simultaneous registration. Elevation was $1800 \mathrm{~m}$, habitat represented by old spruce forest on a steep slope turned to northwest, into a small side-valley.

Records 3 and 4. On September 11, 2005 in the valley of Musalenska Bistritsa stream, at Ikonostasa area. At $6.10 \mathrm{~h}$, and again at $6.15 \mathrm{~h}$, a territorial call of a male Pygmy Owl from the upper part of the steep, almost vertical, rocky, but forested Western slope of the Musalenska Bistritsa valley was heard. The owl called from an old spruce forest at an elevation of $1750 \mathrm{~m}$, about $300 \mathrm{~m}$ from the position of the first author at a rock in $1843 \mathrm{~m}$ a.s. l. The second Pygmy Owl, was heard twice from the opposite (Eastern) slope, but much higher on the slope than the two Tengmalm's owls, it called from an old spruce forest, elevation aproximately $1700 \mathrm{~m}$. It was across the valley probably $1500 \mathrm{~m}$ from the observer, firstly it gave territorial advertising calls and finished with the early morning colourful sounds of owls being in their full autumn mating season.

Records 5 and 6. On September 12, 2005 at $6.05 \mathrm{~h}$ a male Pygmy Owl called from an old spruce forest on a steep slope in a narrow valley called Kamenlivija valley, between the downhill ski track and the ski lift, approximately $1550-1600 \mathrm{~m}$ elevation. Another male Pygmy Owl called at $6.20 \mathrm{~h}$ from a ridge between the rocks of Ikonostasa and the Meždinna stancija of the Jastrebets ski lift, but high on the ridge, in $1950 \mathrm{~m}$ a. s. 1., in an old spruce forest with Macedonian pines. It gave advertising calls, repeted in three series.

After ananlysis of these records of territorial owls in the Northern Rila Mts (in a valley of Musalenska Bis- 


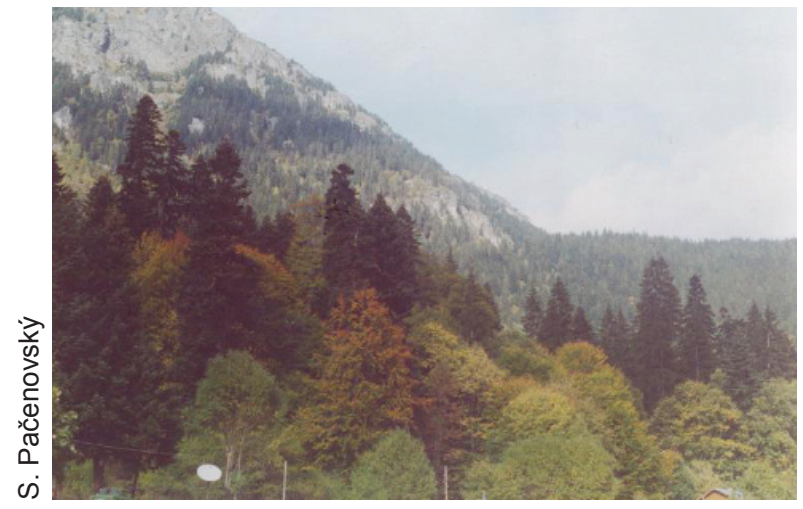

Fig. 4. The Rilska valley, a typical habitat of Pygmy Owl in Bulgaria.

Obr. 4. Dolina Rilskej rieky, biotop kuvička vrabčieho v Bulharsku.

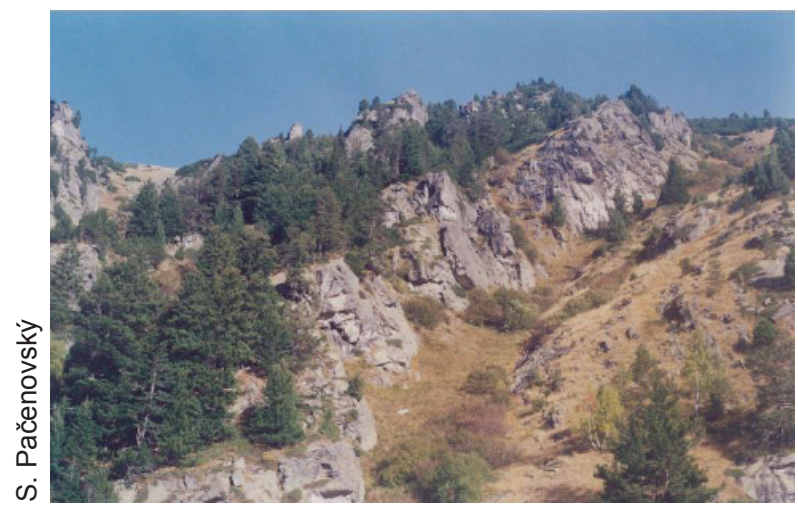

Fig. 5. The tree limit in the Rila Mts in $2000 \mathrm{~m}$ elevation, Bulgaria.

Obr. 5. Horná hranica lesa v pohorí Rila v 2000 m n. m., Bulharsko.

located between 1550 and 1900 m elevations in old spruce forests with Macedonian pines. Except for the downhill ski tracks and clearings for ski lifts no other obvious human impact on these old forest habitats was visible and the condition of the majority of the trees was good, with just a few dried trees, without any evidence of air pollution, or any trees invaded by bast-worms.

Summary of both quantitative surveys in the Rila Mts in Bulgaria is indicated in table 4. In total 9 territories (probably pairs) of Pygmy Owls were located at 23 $\mathrm{km}^{2}$ of monitored areas of suitable mountain habitat and 1 occupied territory falls on $2.6 \mathrm{~km}^{2}$.

Comparative survey from Slovakia Comparative data to the survey done in high mountains of Bulgaria, to estimate densities of Pygmy Owls, were available from the high mountains of Slovakia. Even though the tree limit is situated about 300-400 m lower in Slovakia, than in Bulgaria, the belt of coniferous and mixed forests between $1000 \mathrm{~m}$ a.s. 1 . and the tree limit is regularly and frequently occupied by the Pygmy Owl. Quantitative data for this study were selected from 7 different mountain ranges in Slovakia: the High Tatra Mts, the Low tatra Mts, the Western Tatra Mts, the "Chočské vrchy" Mts, the "Krivánska Malá Fatra" Mts, the "Vel'ká Fatra" Mts and the "Stolické vrchy" Mts. These ranges stretch up from 1400-2600 m elevations (in Bulgaria, the Rila Mts reach $2925 \mathrm{~m}$ a. s. 1.). The tree belt between 1000-1500 m elevations is quite well preserved (especially even till $1650 \mathrm{~m}$ in High Tatra Mts). The majority of the highest mountain ranges in Slovakia were covered by these studies. Only locations over $1000 \mathrm{~m}$ were selected - for better comparison with conditions in Bulgaria even if distribution of the Pygmy Owl in Slovakia runs down following distribution of coniferous (spruce-fir) and mixed (beech-fir, beech-fir-spruce and rarely also oak-fir forest) as low, as till 420 m elevations. At least one quantitative sample was done in each of the 7 mountain ranges over $1000 \mathrm{~m}$ elevation.

\section{The High Tatra and Western Tatra Mts}

Sample 1. The Western Tatra Mts, 29-31 March 2002, 1080-1500 m elevation. Southern, forested, steep slopes of Hlina (Žerucha) and Kotlová, 100 years old, natural, spruce forests with Scots Pine (Pinus silvestris), fir (Abies alba), mountain-ash (Sorbus aucuparia). During quantitative mapping of the 100 ha area by 3 groups of field observers during two evenings and two mornings 10 territories of Pygmy Owls were located. Snow conditions were hard, more than $1 \mathrm{~m}$ of snow cover in the forest, night temperatures below $0^{\circ} \mathrm{C}$. The Pygmy Owls gave advertising calls, all birds located were territorial males, once a female was found within the territory of a male. The quantitative study was done by the first author, E. Baláž and R. Olejár. All the following samples (2-4) from the High Tatra Mts were obtained by S. Pačenovský and R. Olejár between August 29, and September 9, 2002.

Sample 2. The High Tatra Mts, August 29-30, 2002, Holica and Zadná kopa areas between Bielovodská and Javorová valleys in northern part of the High Tatra Mts The habitat is old, natural, spruce forest, 120 years old, with mixed mountain-ash and larch (Larix decidua), in 1350-1650 m elevation, reaching the tree limit of forest, followed in higher elevations by a vegetation zone of dwarf pines (Pinus mugo). It was already the start of au- 
tumn-mating season of most owl species, so vocalisations of owls were suitable for a quantitative survey. During one evening and one morning 8 territories of Pygmy Owls were located in an area of 575 ha (density 1 territory / 70 ha). The Pygmy Owl gave advertising territorial calls (males) and autumn territorial calls.

Sample 3. The area partly belongs to the High Tatras (Kolová valley) and is situated between the High Tatra Mts and the Belanské Tatry Mts - Zadné Med'odoly valley - its left, Southern slope belongs to the High Tatra and its right Northern slope belongs to "Belanské Tatry" Mts. Habitat in "Zadné Med’odoly" and "Kolová dolina" valleys is a taiga-type of old, mountain spruce forest aged aproximately 100 years, growing mostly on peat and covered continuously at ground level by moss. In "Belanské Tatry" Mts it is an old spruce forest, growing on limestone, rocky soils in a steep southern slope, elevations $1350-1600 \mathrm{~m}$.

The study was done on August 30-31, 2002. In an area of $3 \mathrm{~km}^{2} 5$ territories of the Pygmy Owl were located ( 2 pairs and 3 territorial birds giving autumn calls - probably males). The estimated density of Pygmy Owls is 5 territories $/ 3 \mathrm{~km}^{2}$ ( 1 occupied territory / $0.6 \mathrm{~km}^{2}$ ).

Sample 4. "Belanské Tatry" Mts, area in two valleys: "Dolina Siedmich prameňov" and "Dolina Kežmarskej Bielej vody", and a ridge between these valleys. Habitat is a 100 years old spruce forest with a few Pinus cembra pines, in 1100-1530 m elevations. The count was done on August 31, and September 1, 2002.

During one evening and morning (at dusk and dawn) a quantitative sample of 9 territories of Pygmy Owls was located ( 6 males, 3 territorial birds giving autumn calls - probably males), in an area of 370 ha. This density could be explained in two ways: firstly we count only calling males (6), or territorial birds giving autumn calls we have adult birds defending their territory (males or females) and a result is then 1 territory per 40 or 60 ha.

Evaluation of the samples from the High Tatra Mts (all above mentioned sites lay inside the Tatra National Park): Obtained results of these 4 quantitative samples (1 from spring and 3 from end of summer-early autumn season in 2002), base on the Pygmy Owl being a sedentary bird in Central Europe (Scherzinger 1970, Schönn 1980, Hudec 1983) and that it occupies its territory all year and gives territorial calls during this whole period, can be understood as quantitative samples estimated on occupied territories of birds giving advertising - territorial calls of male birds. If we count the territorial birds giving long autumn calls, as likely being territorial males (adult females cannot be completely excluded, however

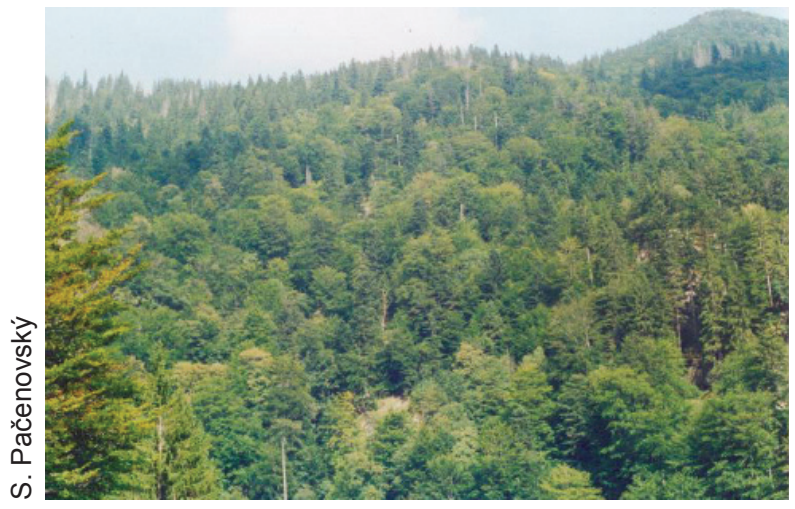

Fig. 2. Habitat of the Pygmy Owl in Šútovská valley in Krivánska Malá Fatra Mts, Slovakia.

Obr. 2. Biotop kuvička vrabčieho v Šútovskej doline, Krivánska Malá Fatra, Slovensko

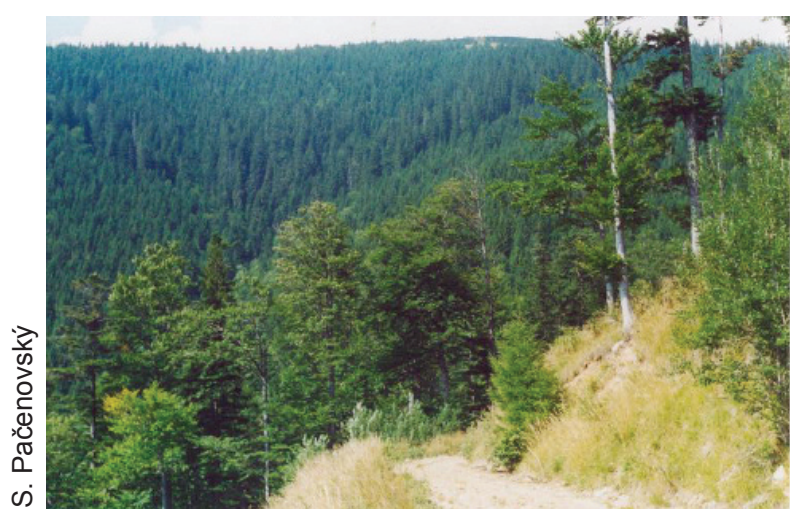

Fig. 3. The Low Tatra Mts, "Bystrá dolina" valley, Pygmy Owl habitat, Slovakia.

Obr. 3. Nízke Tatry, Bystrá dolina, biotop kuvička vrabčieho, Slovensko.

young birds can due to their short autumn calls), we get a sample of more territorial birds. Using the aforementioned interpretation (males only giving advertising calls) 25 territories of likely breeding pairs were found. According to the second interpretation, 32 territories of Pygmy Owls were located, in a total area of $22.5 \mathrm{~km}^{2}$ of forested mountain habitats in 1080-1650 m elevations. Final density of Pygmy Owl pairs in this area is 1 pair ( 1 occupied territory) per $0.78-1 \mathrm{~km}^{2}$.

All quantitative samples of Pygmy Owl densities in the Tatra National park area were obtained in old, natural forests, with minimal human impact. (None of the sample areas were effected by the windstorm in the Tatra National park from on November 19, 2004, destroying 14000 ha of forests.) Most of these destroyed forests were non-native, planted spruce forests in aged about 80 years 
planted after a similar storm, which destroyed large areas of forests. Native forests in the Tatra Mts consist not only from spruce, they overtake several succession stages and consist of poplar, mountain-ash, maple, fir, pine and also other tree species, mixed in between the spruce.

Health condition of native forests, which consist of natural tree structure, is usually better and they can resist different stress factors (as storms, diseases, bast-worm, e.g.).

Pygmy Owls occupy also planted, secondary spruce forests in many lower mountain areas of Slovakia. Even if comprehensive data on densities of Pygmy Owls from secondary, intensively managed forests from the High Tatra Mts are missing, some data are available from other, lower mountain elevations, however there are no striking differences between densities of Pygmy Owl in lower and higher elevations in Slovakian forests.

\section{The Low Tatra Mts}

Sample 1. Counts of owls were carried out during spring (20-22 April) and autumn (21-22 September) in 2002 by P. Chrašč, R. Olejár, S. Pačenovský, P. Vrlík and other field researchers. Combination of two quantitative surveys in different seasons, both important for vocalisation of owls were selected. It was suitable for creating complex picture of an owl community in the valley, as some owl species call in both seasons (Pygmy owl, Ural owl, Tawny owl), but the Pygmy Owl calls less frequently in the second half of April, than in autumn. Location of the survey was at the end of the "Svarínska" valley, its side-valleys called "Torysa" and "Ústredok", below mountain "Vel'ký bok", in Northern part of the Low Tatra Mts, in 1250-1550 m elevations. The habitat is $80-120$ years old spruce, fir-beech with old maple (Acer pseudoplatanus) trees, in some parts remote: almost primeval forest - like habitats in steep, rocky slopes. During several evening, morning and night observations the results revealed vocalisations of 7 territories of Pygmy Owls per 600 ha equals 1 territory per 85.7 ha.

Sample 2. In the "Dumbier" massif area, on the Southern side of the main ridge of the Low Tatra Mts, at the end of the Mlynná valley, at 1000-1400 m elevation. Habitat is $80-120$ years old spruce-fir-beech forest with patches of young spruce plantations, stretching up to the tree limit. The survey was carried out by the first author of the study and R. Olejár, on August 24-25, 2002. Vocalisations of 3 territorial males of Pygmy Owl were found and 1 further adult bird was observed, in a total of 4 territories per 550 ha (1 territory / 140 ha). Result for the Low Tatra Mts after summary of both samples: 11 territories of Pygmy Owls per 1100 ha $\left(1\right.$ territory $\left./ 1 \mathrm{~km}^{2}\right)$.

3. “Krivánska Malá Fatra” Mts

Area south from the Chleb mountain $(1670 \mathrm{~m})$, in valleys "Šútovská dolina", "Snilovská dolina" and "Studenec", at 1000-1300 m elevations, in habitat of 80-120 years old beech-spruce, spruce and fir-beech forests, reaching the tree limit and the dwarf pine zone (in $1400 \mathrm{~m}$ ). Survey of owls was done in a remote, hardly accessible area covered by old, native forests. The $20 \mathrm{~km}^{2}$ area was surveyed on September 7-8, 2002 by the first author and R. Olejár. During two evenings and one morning 8 territories per $12 \mathrm{~km}^{2}$ of Pygmy Owls were found (1 territory $\left./ 1.5 \mathrm{~km}^{2}\right)$.

\section{4. "Chočské vrchy" Mts}

The survey carried out in the Eastern part of "Chočské vrchy" Mts, in Prosečné range, north from villages Liptovská Anna and Prosiek (Pravnáč, Lomné and "Prosiecka dolina" valley sites) on August 13-16, 2002 by the first author. This was in a total area of 500 ha at $900-1250 \mathrm{~m}$ elevations, in habitats of 80-120 years old spruce forests with a small amount of beeches and in spruce-fir-beech forests, including remote areas, with very little human interference during the last few decades. Vocalisations of owls were registered during evening (dusk) and early morning (dawn). Some Pygmy Owls called sporadically during daytime. Evening observations ended one hour after sunset. Vocalisations of Pygmy Owls were typical to autumn mating season, with advertising calls of males and autumn calls. Number of located Pygmy Owl territories was 5 per 500 ha $\left(1\right.$ territory $\left./ 1 \mathrm{~km}^{2}\right)$.

\section{5. "Vel'ká Fatra" Mts}

In central part of "Vel'ká Fatra" Mts a $7.5 \mathrm{~km}^{2}$ area, at 1000-1400 m a.s. 1. close to localities of Lysec, Borišov and Ploská was surveyed. Habitat was 100 years old spruce-beech forest. Owl counts were carried out on April 13-14, 21-22, and September 21-22, 2002 by the first author and R. Olejár. The spring survey was done in deep snow and cold weather conditions; the autumn survey was done in relatively mild weather. Results are as follows: 10 territories of Pygmy Owl per $7.5 \mathrm{~km}^{2}$ (1 territory / 0.75 $\mathrm{km}^{2}$ ). The results show, that the Pygmy Owl is one of the two most common owl species not only in the "Vel'ká Fatra" Mts, but in all high mountain ranges of Slovakia. It seems, that the Pygmy Owl is more common, than the Tengmalm`s Owl, but those results could be affected by the selected method; concentrating more on autumn 
Slovak Rapt J 2008, 2: 91-106. DOI: 10.2478/v10262-012-0023-5.

(C) Raptor Protection of Slovakia (RPS)

Tab. 5. Pygmy owl's population density in high mountains of Slovakia - review

Tab. 5. Populačná denzita kuvička vrabčieho vo vysokých pohoriach Slovenska - prehl'ad

\begin{tabular}{|c|c|c|c|c|c|}
\hline Mountain range / Pohorie & $\begin{array}{l}\text { Elevation / } \\
\text { Nadmorská } \\
\text { výška } \\
\text { [m] }\end{array}$ & $\begin{array}{c}\text { Surveyed } \\
\text { area / } \\
\text { Prieskumná } \\
\text { oblast' } \\
\text { [km²] }\end{array}$ & $\begin{array}{l}\text { No. of territories / } \\
\text { Počet teritórií }\end{array}$ & $\begin{array}{c}\text { Density / } \\
\text { Denzita } \\
\text { [territory } / \mathbf{k m}^{2} \text { ] }\end{array}$ & $\begin{array}{c}\text { Size of one } \\
\text { territory I } \\
\text { Vel'kost' jedného } \\
\text { teritória }\left[\mathrm{km}^{2}\right]\end{array}$ \\
\hline West and High Tatra Mts & $1080-1650$ & 22.5 & $25-32$ & $1.1-1.4$ & $0.7-0.9$ \\
\hline Low Tatra Mts & $1000-1550$ & 11.0 & 11 & 1,0 & 1,0 \\
\hline Krivánska Malá Fatra Mts & $1000-1300$ & 12.0 & 8 & 0.67 & 1,5 \\
\hline Chočské vrchy Mts & $900-1250$ & 5.0 & 5 & 1 & 1,0 \\
\hline Vel'ká Fatra Mts & $1000-1400$ & 7.5 & 10 & 1.33 & 0,75 \\
\hline Stolické vrchy Mts & $800-1200$ & 16.0 & 16 & 1 & 1,0 \\
\hline $\begin{array}{l}\text { Average density / } \\
\text { priemerná hustota }\end{array}$ & $800-1650$ & 79.0 & $75-82$ & $0,95-1.04$ & $0.96-1.05$ \\
\hline
\end{tabular}

counts than spring season (Tengmalm`s Owls in Slovakia usually do not give territorial calls in autumn).

\section{6. "Stolické vrchy" Mts}

Surveys from all above mentioned mountains of Slovakia (1-6) were conducted by intensive, but short-term owl counts, so comparing these data with long-term quantitative surveys done on large areas (Scherzinger 1970, Kloubec 1987, Bezzel \& Lechner 1978) is limited. However the long-term comparative survey from "Stolické vrchy" Mts supports all data obtained in other high mountains of Slovakia, the results are very similar.

The survey from "Stolické vrchy" Mts was included in this study, because this range also belongs to higher mountains (reaching $1476 \mathrm{~m}$ ). Some habitat types present in the Rila Mts in Bulgaria are missing in "Stolické vrchy" Mts (e. g. dwarf-pine zone, mountain zone with bare rocks over forest line), however, the belt of mainly coniferous forests is stretching up as high, as $1300 \mathrm{~m}$, so some level of similarity is still present. An advantage is good data coverage, results of systematic mapping works in both spring and autumn seasons (March, April and October) 1990-1999. The data are fully comparable with other long-term results, as well as with data of systematic research done in lower elevations in Slovakia (Pačenovský 1995).

16 territories of the Pygmy Owl (1 territory / $1 \mathrm{~km}^{2}$ ) were found in 60-100 years old spruce, spruce-beech forests in Northeastern part of the "Stolické vrchy" Mts, nearby Rejdová village on Eastern slopes of the Stolica mountain in "Mlynná", "Zelinová" and "Slanská" valleys in $16 \mathrm{~km}^{2}$ area. The average density of Pygmy Owl population for the surveyed comparative sample area of $79 \mathrm{~km}^{2}$ in the high mountains of Slovakia (all of them belong to Western Carpathians) is 1 territory per $0.96-1.05 \mathrm{~km}^{2}$.

\section{Discussion}

Comparison of quantitative data in Bulgaria and Slovakia

The results from Slovakia showed average population density of Pygmy Owl of 0.95-1.038 territories per $1 \mathrm{~km}^{2}$ and no significant difference was found between the highest and the lowest located densities in elevations over $1000 \mathrm{~m}$. In comparison to Bulgaria, Pygmy Owl population recorded an average density of only 0.39 territories per $1 \mathrm{~km}^{2}$. Ascertained densities in the mountains of Bulgaria were more than twice as low as those in localities of comparable elevation in Slovakia. From high mountains in Slovakia only densities in the "Krivánska Malá Fatra" Mts $\left(0.67 / 1 \mathrm{~km}^{2}\right)$ were below 1 territory per $1 \mathrm{~km}^{2}$. All other comparative samples from higher elevations in Slovakia showed much higher densities, than both samples obtained in Bulgaria (Tabs 4 and 5). When we exclude differences in methodology (all quantitative samples were obtained by similar methods), possible explanations for differences faund could be as follows:

- specific habitat and environmental differences between the two study areas. This includes climatic and vegetation distribution differences and thus different ecological amplitude of Pygmy Owl. Even if both areas share some climatic similarities (e.g. usually high snowfall in winter), the Rila Mts are situated in the Balkans, with considerably higher average temperatures compared to the Slovakian part of Western Carpathians, e.g. the High Tatra Mts, considered the coldest of all Central European mountains. The forest line goes higher in the Balkans, at 1900-2000 m approximately, in Slovak Carpathians (High Tatra Mts, Low Tatra Mts, the Fatra Mts) the forest line is situated at $1500 \mathrm{~m}$ elevation. The distributions of Pygmy Owls in both countries follow the forest up to the 
forest line. Pygmy Owl population in Slovakia show wide ecological amplitude: the species breeds from $420 \mathrm{~m}$ up to $1600 \mathrm{~m}$ in the High Tatra Mts and occupies not only coniferous forests in high mountains, but also coniferous and broad-leaved forests (spruce-beech-fir, beech-fir and oak-fir forests) in much lower elevations, than $1000 \mathrm{~m}$ a.s. 1. (Pačenovský in Danko et al., 2002). In Bulgaria, according to previous data (Tab. 1), the Pygmy Owl shows much narrower ecological amplitude: it breeds only in forests of high mountains, probably only over $1000 \mathrm{~m}$. This fact alone does not explain lower densities of the Pygmy Owl in Bulgaria, but indicates that for some reasons the species is less distributed in the Balkans than in Central Europe.

Reasons for that narrow ecological amplitude of the Pygmy Owl in Bulgaria could be as follows:

- food supply. According to our knowledge on diet of the Oygmy Owl it seems, that distribution of small Passerines is comparable with Central Europe (e. g. Mikkola \& Sackl 1997). Wide distribution of the Tengmalm`s Owl in Bulgarian mountains (Nikolov et al. 2004, Nankinov 2002, Nankinov et al. 2004, Shurulinkov \& Stoyanov 2006) indicates sustained populations of small mammals, probably the main component of the Pygmy Owl's diet. Thus it is unlikely that lack of food is an important factor.

- quality of habitat and human activities. This factor apparently does not explain different densities of the Pygmy Owl populations in this two countries, because forests in the Rila Mts are in good health condition, without patterns of air pollution or bast-worms, contrary to some areas in Slovak mountains affected by these beetles. Also age, condition of forests and level of human impact (logging, disturbance) is much higher in some parts of Slovakian Carpathians, than in studied areas of the Rila Mts.

- possible competition with other species. Possible competitive or predatory behaviour of the Tengmalm's Owl towards the Pygmy Owl was reported by Mikkola (1983), however, ecological isolation of these two species is quite strong due to some differences in their diet and different timing of their activity (Mikkola 1983). The conclusion is, that even if these two owls occupy sympatrically some mountains of Bulgaria, their competition is probably low and do not considerably effect the population densities of the Pygmy Owl. The Tawny Owl is known as possible predator of the Pygmy Owl (Mikkola 1983) and it is thought to be one important reason for limiting the distribution of this species into lower elevations in some regions of Germany and Aus- tria (Scherzinger 1970, 1974, Schönn 1980). In Slovakia sometimes these two species inhabit the same types of forests (present study), although the Tawny Owl prefers broadleaved forests and the Pygmy Owl prefers conifers (Pačenovský 1995, Danko et al. 2002). In the Rila Mts a sympatric occurrence was found of the Pygmy Owl and the Tawny Owl and the latter was recorded as high as $1600 \mathrm{~m}$, however the Tawny Owl does not seem to limit densities of the Pygmy Owl in elevations above $1000 \mathrm{~m}$. It could be one of the reasons why the Pygmy Owl does not occupy lower elevations in the Rila Mts, where Tawny Owls are more abundant.

Further possible factors of different Pygmy Owl population densities in Rila Mts and mountains in comparative survey from Slovakia:

- lack of breeding holes. As the Pygmy Owl is confined to breeding in woodpecker holes excavated by the Great-spotted, the Three-toed and the Grey-headed woodpeckers (Scherzinger 1970), it is believed, that the rarity of these woodpecker species in the Rila Mt could be a contributing factor towards lower densities of Pygmy Owls. It is known, that the Three-toed Woodpecker seems to be extremely rare in Bulgaria, although the Grey-Headed Woodpecker was found at Borovets on September 10-12, 2005 at the same site, as the Pygmy Owl in $1500 \mathrm{~m}$. The Great Spotted Woodpecker was also found in density of 8 specimen per 30 ha at elevations 1350-2000 m over Borovets on September 10-12, 2005. This density is comparable to the densities of the Great Spotted Woodpecker in Slovakian Carpathians. Thus a lack of woodpecker holes could not bee deemed as a major limiting factor for the Pygmy Owl population densities in the Rila Mt.

- abiotic factors (twilight owl activity). The Pygmy Owl is active during daylight - it is an adaptation to Northern conditions with long twilight. This rhythm of activity, preserved also in Central Europe, where it has migrated probably during postglacial period together with the conifers from Siberian taiga (Scherzinger 1970). A similar way of distribution could act as a factor for the Pygmy Owl also in the Balkans. Its distribution seems to be historically tied to conifers and their distribution. The Pygmy Owl in the Alps is most active during the morning and evening hours: morning activity lasts an average of 36 minutes, evening activity only 35 minutes (Scherzinger 1970). Morning and evening activities of Pygmy Owl were studied and confirmed in Slovakia (Pačenovský \& Kürthy 1992) and average morning activities last longer, than evening ones. Periods of vocalisations lasted in Slovakia a maximum of 20-40 minutes. As a result of 


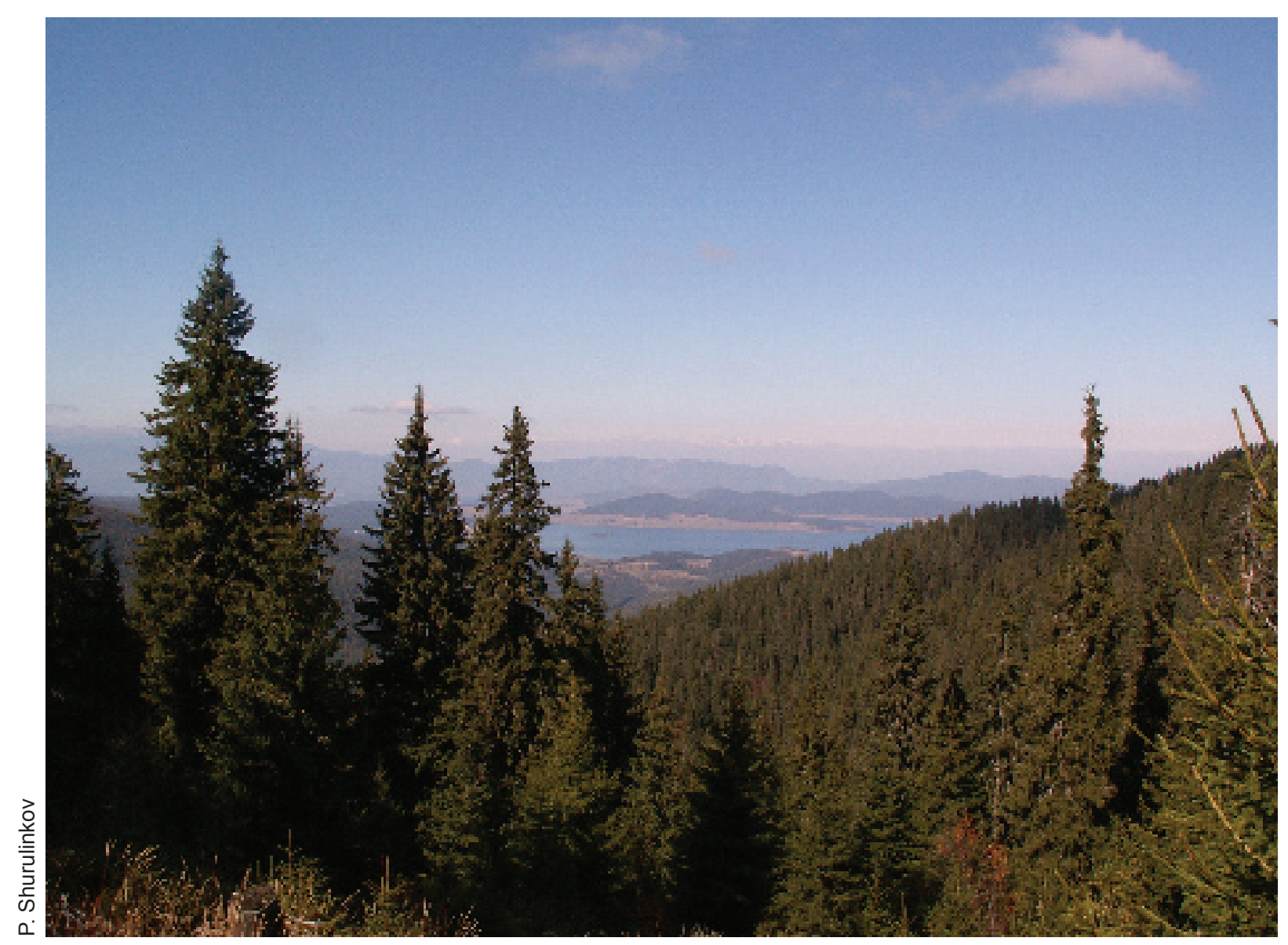

Fig. 6. Pygmy Owl habitat in Western Rodopi Mts, Bulgaria.

Obr. 6. Biotop kuvička vrabčieho v Západných Rodopách, Bulharsko.

twilight being shorter in Bulgaria than in Central Europe, the vocalisation period observed seems to be relatively shorter.The Pygmy Owl at Sintyakovo (Rila Mts, Borovets area) called in the morning of the 10th of September 2005 for only 6 minutes and at Ikonostasa area the owls called in the morning of the 11th.September 2005 (Rila Mts, North of Borovets) for 10 minutes. Owing to the shortness of the calling period in Bulgaria, in comparison with Central or Northern Europe (Mikkola 1983), it is quite difficult to locate these owls. In Central Europe and Nothern Europe the Pygmy Owl is active 24 hours during breeding season, with peaks after sunset ( 22 hours) and before sunrise (1.30 hours). This may, partly explain, why this owl species was considered to be so rare in Bulgaria for a long time, but it does still not explain its low densities in the Rila Mts in comparison with Slovak mountains, for example. It could simply be that the owls have less chance to form pairs, if they only call for such a small amount of time. Specific factor for Rila Mts (spatial concentration of streams). One specific factor possibly effecting the spatial distribution of Pygmy Owl territories in the Rila Mts is the high spatial concentration of streams and the natural noise caused by these streams. This noise seems to have an effect on the location of males' calling places. All Pygmy Owl territories located by the authors in Rila valley, or at Borovets area were situated high up on the slopes or on the ridges, far from any stream. These positions seem to be more suitable for vocalisations: to mark their territories and to attract females by calling. In the valleys their calls could be hardly located by other conspecific birds due to high noise caused by the streams and therefore is the primary reason as to why the calls could not be heard. This factor could explain, why the owls call so high (and not lower down in the valleys), but still can not explain fully the low densities of Pygmy Owls in Rila Mts, because in 
the High Tatra Mts concentration of streams is comparable to Rila Mts (High Tatra: 12 streams $/ 10 \mathrm{~km}^{2}$ in 4 sampled areas, Rila: 11 streams $/ 10 \mathrm{~km}^{2}$ in 2 surveyed areas). However densities of Pygmy Owls are higher in the Tatra Mts. The effect of streams on distribution of Pygmy Owl territories seems to be a greater factor in the Rila Mts, possibly due to the higher distribution of forests and streams reaching over $1500 \mathrm{~m}$ a.s. 1. (in the High Tatras, and other Slovak mountain ranges, the forest limit seldomly overrun $1500 \mathrm{~m}$ and do not reach 1600 $\mathrm{m}$, so the presence of streams in these high elevations do not effect the Pygmy Owls, as they are absent at that height due to the lack of forests).

- Isolation of the Pygmy Owl distribution in Bulgaria and its history. As the most important factor causing lower densities of the Pygmy Owl seems to be, that isolation of the species is high in the Balkans, where apparently the species is tied only to high mountain conditions and individual micropopulations became quite isolated. Likely this is also the main reason for lower densities in comparable elevations and similar habitats in the Slovak Carpathians. Another possible cause could be the historical distribution of the species probably in postglacial period, when it seems, that its distribution to the South occurred from the Northern taiga (Scherzinger 1970) and the distance from the taiga belt to the Balkans is higher, than the distance of Slovakia from the taiga.

Zonal distribution of the Pygmy Owl in Bulgaria lays between $1000 \mathrm{~m}$ to the treeline in 1800-1900 m a. s. 1. In Slovakia the treeline is situated in a much lower elevation of $1500 \mathrm{~m}$ to $1650 \mathrm{~m}$ maximum, but it is also followed by the Pygmy Owl to its highest limit. In the Alps the species inhabits the forests above the highest nesting territories of the Tawny Owl from 700-1000 m a. s. 1. to the treeline at 1800-2100 m (Mikkola \& Sackl 1997). In the Šmava Mts in South Bohemia the species reaches $1260 \mathrm{~m}$ (Kloubec 1987).

Quantitative data presented in this study: 9 terit. per $23 \mathrm{~km}^{2}$ (1 ter. $\left./ 2.5 \mathrm{~km}^{2}\right)$ for Bulgaria and 75-82 territories per $79 \mathrm{~km}^{2}$ (1 ter. / 0,96-1.05 km²) for Slovakia are both comparable with data published from other parts of the European distribution range of the species (Scherzinger 1970, 1974, Glutz von Blotzheim \& Bauer 1980, Kloubec 1987). To data of these authors were obtained by longterm research and densities were extrapolated to large geographic areas: Scherzinger found 50 territories in an area of $120 \mathrm{~km}^{2}$ in Bayerischer Wald (1.4pairs / $10 \mathrm{~km}^{2}$ ), in Bayerischen Alpen found Bezzel \& Lechner (1978) $100-150$ territories in an area of $864 \mathrm{~km}^{2}(1.2-1.7$ pairs / $10 \mathrm{~km}^{2}$ ), Kloubec extrapolated the average density for the forests of the whole range of Šmava Mts as 1 pair per $3 \mathrm{~km}^{2}$ and our data reflects only the surveyed plots and while further surveys are incomplete, estimation on broader areas can not be concluded. Still, densities presented in our study are supporting knowledge on the size of a Pygmy Owl territory, stated by Scherzinger for the Alps and Bayerischer Wald 0,45-1,9 on average per approx. 1,25 km² (Glutz von Blotzheim \& Bauer 1980). A quantitative study carried out in 1989-1992 in the "Volovské vrchy" Mts in Slovakia at 420-1100 m a.s.l (Pačenovský 1995) found a density of 46 pairs per 200 $\mathrm{km}^{2}$ (2.3 pairs $/ 10 \mathrm{~km}^{2}$ ) and it was obtained by long-term systematic research, using the same method of recording owl territories as in the present study. Local densities in the Volovské Mts (15 pairs / $20 \mathrm{~km}^{2}$ ) were similar to those in this study. In the "Stolické vrchy" Mts (sample area 7 in the present study) the area of $16 \mathrm{~km}^{2}$ surveyed systematically during years 1990-1999 recorded a density of 16 pairs equalling 1 pair per $1 \mathrm{~km}^{2}$, which was found at 800-1200 m a. s. 1. In Scandinavia the population densities vary between 0.15 and $20-30 \mathrm{bp}$. per $10 \mathrm{~km}^{2}$, probably fluctuating depending on weather and rodent cycles. Northern Austria are reaching localised densities of 3-4 bp. per $1.5 \mathrm{~km}^{2}$ (Mikkola \& Sackl 1997). The highest local densities in Southwestern Bohemia were in small forests in lower elevations in the area close to Tachov 1 pair per $1.25 \mathrm{~km}^{2}$ (Kloubec 1987).

To conclude that comparison with densities in our study with broader data from Europe, it seems, that both data from Bulgaria and Slovakia are comparable to densities from other parts of the European distribution range of the Pygmy Owl. So, lower densities ascertained for Bulgarian mountains seem to be not considerably lower, than the European average. Still, the apparent difference between comparatively lower densities in Bulgarian mountains than in Slovak mountains obtained by the same method lead us to look for possible explanations, the most probable seem to be geographical isolation, edge of distribution range, short time of twilight and high spatial distribution of streams in elevations between 1300-1900 m in the Rila Mts in Bulgaria.

New distribution data. The new data as presented in this study, regarding distribution of the Pygmy Owl in Bulgaria means that the previous findings can be amended. Data presented in this study regarding are new and therefore is a need to correct previous data on distribution of the species from Bulgaria. Moreover, comparative data obtained from 800-1600 m a.s. l. in Slovakia contribute to the knowledge on distribution and densities of the Pygmy Owl. 


\section{References}

Bezzel E \& Lechner F 1978: Die Vögel des Werdenfelser Landes. Vogelkundliche Bibliothek, Bd. 8. KildaVerlag Greven, 243.

BirdLife International 2004: Birds in Europe: population estimates, trends and conservation status. BirdLife Conservation Series 12. Cambridge, 374.

Danko Š 1988: Doterajšie poznatky o kuvičkovi vrabčom (Glaucidium passerinum) vo Východoslovenskom kraji. Haja 3-4: 61-73.

Danko Š, Darolová A \& Krištín A (eds) 2002: Rozšírenie vtákov na Slovensku. Birds distribution in Slovakia. Veda, Bratislava, 686.

Ferianc O 1979: Stavovce Slovenska II. Vtáky 1. Veda, Bratislava, 683.

Glutz von Blotzheim UN \& Bauer KM 1980: Handbuch der Vögel Miteleuropas. Band 9 Columbiformes - Piciformes. Akademische Verlagsgesellschaft. Wiesbaden, 1148.

del Hoyo J, Elliott A \& Sargatal J (eds) 1999: Handbook of the birds of the world, Vol. 5. Barn owls to hummingbirds. Lynx Edicion, Barcelona, 759.

Hudec K (ed) 1983: Fauna ČSSR, svazek 23. Ptáci-Aves 3/I. Academia. Praha, 704.

Janda J \& Řepa P 1986: Metody kvantitativního výzkumu v ornitologii. SZN. Praha, 160.

Klaus S, Klaus M \& Bräsecke R 1982: Beobachtungen an einem Brutplatz des Sperlingskauzes in der Belaer Tatra (Belanské Tatry, ČSSR). Falke 29(10): 330-336.

Kloubec B 1987: Rozšíření, početnost a ekologické nároky kulíška nejmenšího Glaucidium passerinum L. v jižních Čechách, 116-136. In: Anonymus (ed): Sborník Avifauna jižních Čech a její změny 1. Sborník přednášek z I. jihočeské ornitologické konference konané ve dnech 22.-23. února 1986 v Českých Budějovicích. Dom kultury ROH, České Budějovice, 136.

Kostadinova I (ed) 1997: Important Bird Areas in Bulgaria. Conservation series 1. Bulgarian Society for the Protection of Birds, Sofia, 57.

Kostadinova I \& Michailov M (eds) 2002: Natura 2000 in Bulgaria. Nature conservation series 5. Bulgarian Society for the Protection of Birds, Sofia, 80 .

Kouzmanov G, Todorov R \& Stoyanov G 1995: Information sur la repartition et la situation des rapaces nocturnes en Bulgarie. Newsletter WWGBP 21/22: 14-17.

Mikkola H 1983: Owls of Europe. T \& AD Poyser, Calton, 397.

Mikkola H \& Sackl P 1997: Glaucidium passerinum Pygmy Owl, 406-407. In: Hagemeijer EJM \& Blair
MJ (eds) 1997: The EBCC Atlas of European breeding birds: their distribution and abundance. T \& AD Poyser, London, 903.

Murin B, Krištín A, Darolová A, Danko Š \& Kropil R 1994: Početnost' hniezdnych populácií vtákov na Slovensku. Sylvia 30: 97-105.

Nikolov B, Hristov I, Shurulinkov P, Nikolov I, Roguev A, Dutsov A \& Stanchev R 2001: New data on some poorly-studied forest species of owls (Srix uralensis, Glaucidium passerinum, Aegolius funereus) in Bulgaria. Forest Sci 38(1/2): 75-86.

Nankinov D 2002: [Recent state of owls populations in Bulgaria]. Berkut 11(1): 48-60. [in Russian]

Nankinov D, Dutsov B, Nikolov B, Borissov B, Stoyanov G, Gradev G, Georgiev D, Popov D, Domuschiev D, Kirov D, Tilova E, Nikolov I, Ivanov I, Dichev K, Popov, K, Karaivanov N, Todorov N, Shurulinkov P, Stanchev R, Aleksov R, Tsonev R, Dalakicheva S, Ivanov S, Marin S, Stajkov S, Nikolov S \& Nikolov H 2004: Breeding totals of the ornithofauna of Bulgaria, 2004. Green Balkans, Plovdiv, 32.

Pačenovský S 1990: Rozbor potravy Glaucidium passerinum z dvoch hniezd na východnom Slovensku. Tichodroma 3: 87-101.

Pačenovský S 1992: Výskyt sov a d'atl'ov v pramennej oblasti Bodvy, 182-189. In: Fulín M (ed): XV. Východoslovenský tábor ochrancov prírody a krajiny 1991. Prehl'ad odborných výsledkov (Štós-Porča, 28.7.-2.8. 1991). Okresný úrad životného prostredia Košice vidiek, Moldava nad Bodvou, 221.

Pačenovský S 1994: K aktivite a spotrebe potravy kuvička vrabčieho (Glaucidium passerinum). Tichodroma 5: $17-21$.

Pačenovský S 1995: Poznámky k výskytu niektorých druhov sov v Národnom parku Slovenský raj, 88-91. In: Zborník z odborného seminára k 30. výročiu ochrany prírody Slovenského raja, Čingov, 25.-26. október 1994. Ministerstvo životného prostredia SR \& Správa NP Slovenský raj, Bratislava \& Spišská Nová Ves, 134.

Pačenovský S 1995: K medzidruhovým vzt’ahom Glaucidium passerinum, Strix uralensis a Strix aluco. Tichodroma 8: 61-73.

Pačenovský S 1996: Sovy na Starej planine v Bulharsku. Buteo 8: 109-112.

Pačenovský S 2005: Kuvičok vrabčí. Jeho rozšírenie, biotop a ochrana na Slovensku, metódy výskumu a monitoringu. Vtáčie správy 12(4): 4-5.

Pačenovský S \& Kürthy A 1991: Nové výsledky výskumu rozšírenia kuvička vrabčieho (Glaucidium 
passerinum) na východnom Slovensku a niekol'ko poznámok k jeho etológii a hniezdnej bionómii. Buteo 4: 63-72.

Pačenovský S \& Kürthy A 1992: Zhodnotenie priebehu jesenného toku kuvička vrabčieho (Glaucidium passerinum) na základe hlasových prejavov. Zborn Východoslov Múz, Prír Vedy, Košice 32-33: 55-68.

Pačenovský S \& Matis Š 1997: Príspevok k poznaniu rozšírenia, biotopu a početnosti sov (Strigidae) v CHKO Slovenský kras, 136-143. In: Rozložník M \& Šmídt J (eds): Ochrana krasových javov a krasových území. Zborník referátov odborného seminára pri príležitosti 20. výročia vyhlásenia Biosférickej rezervácie Slovenský kras. Správa CKO Slovenský kras, Brzotín, 150.

Pateff P 1950: Birds of Bulgaria. Bulgarian Academy of Sciences, Sofia, 428.

Rác P (ed) 1987: Ornitologické pozorovania. Tichodroma 1: 166-173.

Scherzinger W 1970: Zum Aktionssystem des Sperlingskauzes (Glaucidium passerinum L.). Zoologica 41: $1-120$.

Scherzinger W 1974: Zur Ökologie des Sperlingskauzes Glaucidium passerinum im Nationalpark Bayerischer Wald. Anz Orn Ges Bayern 13(2): 121-156.

Schönn S 1980: Der Sperlingskauz. Neue Brehm Bücherei 513. A. Ziemsen, Wittenberg Lutherstadt, 123.
Shurulinkov P \& Stoyanov G 2005: Über die südlichste Grenze des Sperlingskauz-Vorkommens Glaucidium passerinum. Orn Mitt 57(6): 198-200.

Shurulinkov P \& Stoyanov G 2006: Some new findings of Pygmy Owl Glaucidium passerinum and Tengmalm's Owl Aegolius funereus in Western and Southern Bulgaria. Acrocephalus 27(128-129): 65-68.

Simeonov S, Michev T \& Nankinov D 1990: Fauna of Bulgaria. Vol. 20. Aves. Part 1. Bulgarian Academy of Sciences, Sofia, 351.

Spiridonov J 1999: Breeding ornithofauna of NP "Rila" and its conservation importace, 385-414. In: Sakalyan M (ed): Biodiversity of NP "Rila". USAID.

Spiridonov J \& Mileva L 1988: Endangered and rare bird species in "Steneto" biosphere reserve. Orn Inf Bull 23/24: 99-105.

Spiridonov J, Mileva L \& Spassov N 1987: Breeding ornithofauna of "Tsarichina" biosphere reserve, 104-121. Polish Academy of Sciences, Bulgarian Academy of Sciences, Krakow.

ŠOP SR 2002: Národný zoznam navrhovaných chránených vtáčích území. Štátna ochrana prírody SR, Banská Bystrica, http://www.sopsr.sk/.

Št’astný K, Randík A\& Hudec K 1987: Atlas hnízdního rozširrení ptáků v ČSSR 1973/77. Academia. Praha, 484.

Todorov N 1983: Birds of the ornithological station "Dragichevo". Orn Inf Bull 13-14: 37-58. 